\title{
Chemical Composition and Fatty Acid Profile of Small Pelagic Fish (Amblygaster sirm and Sardinella gibbosa) from Muara Angke, Indonesia
}

\author{
SUGENG HERI SUSENO*, CHALIDA SYARI, ENOK RIKA ZAKIYAH, \\ AGOES MARDIONO JACOEB, AYU FITRI IZAKI, SARASWATI and SRI HAYATI
}

Faculty of Fisheries and Marine Sciences, Department of Aquatic Product Technology, Bogor Agricultural University, Bogor 16680, Indonesia.

${ }^{*}$ Corresponding author E-mail: sug_thp@yahoo.com

http://dx.doi.org/10.13005/ojc/300328

(Received: July 07, 2014; Accepted: August 06, 2014)

\begin{abstract}
Knowledge of fish proximate composition is essential to estimate energy value and to plan appropriate industrial and commercial processing. The highest fat content was found in viscera of spotted sardinella $(7.30 \%)$ and head of goldstrip sardinella $(4.43 \%)$. The highest protein content was found in whole part (19.57\%) and meat (17.99\%) of spotted sardinella and whole part of goldstrip sardinella $(22.32 \%)$. Viscera of spotted sardinella $(A$.sirm $)$ had the highest fatty acids, that is palmitic acid $(19.98 \%)$, oleic acid $(5.97 \%)$ and DHA $(21.32 \%)$. The highest fatty acid contents in goldstrip sardinella (S.gibbosa) were palmitic acid (15.93\%), palmitoleic acid $(5.35 \%)$ and DHA $(12.18 \%)$.
\end{abstract}

Key words: Fatty acids, goldstrip sardinella, proximate, spotted sardinella.

\section{INTRODUCTION}

The term 'small pelagic fishes' refers to diverse group of mainly planktivorous fishes that share the same habitat, the surface layers of the water column, usually above the continental shelf and in waters not exceeding $200 \mathrm{~m}$ in depth. One of the small pelagic fishes can be defined as the clupeoids (Engraulidae, Clupeidae) with common name as sardines. Genus of sardines fish include Sardinella spp. and Amblygaster spp. ${ }^{6}$. Production of small pelagic fish in Indonesia has increased from 2008 to 2012 of $2.29 \%$. Small pelagic fish production in 2012 reached $1,637,056$ tons $^{7}$.
Spotted sardinella (Amblygaster sirm) in Indonesia called 'Siro' is a pelagic fish habitat in the waters of the reef with a depth of 10-75 m. Spotted sardinella distribution in Indonesia is West Java, Central Java, and East Java. Goldstrip sardinella (Sardinella gibbosa) in Indonesia called 'Tembang' is one of the small pelagic fish found in tropical waters with a depth of about 10-70 m. Deployment region of goldstrip sardinella is in coastal pelagic almost all Indonesian namely West Papua, West Sulawesi, Papua, North Maluku, Maluku, Gorontalo, South East Sulawesi, South Sulawesi, Central Sulawesi, North Sulawesi, East Kalimantan, South Kalimantan, Central Kalimantan, West Kalimantan, East Nusa 
Tenggara, West Nusa Tenggara, Bali, Banten, East Java, Yogyakarta, Central Java, West Java, Jakarta, Riau Islands, Bangka Belitung, Lampung, Bengkulu, South Sumatra, Jambi, Riau, West Sumatra, North Sumatra, and Aceh ${ }^{9-10}$. Spotted sardinella production in Indonesia in 2012 amounted to 49,110 tons. While goldstrip sardinella production in Indonesia in 2012 reached 161,839 tons $^{8}$.

Fish is a major source of food for human nutrition providing an important amount of protein and lipid in the world. Generally, chemical composition of whole fish is 70 to $80 \%$ of water, 20 to $30 \%$ of protein, and 2 to $12 \%$ of lipid ${ }^{13}$. Knowledge of the proximate composition of fish is essential to estimate their energy value and to plan the most appropriate industrial and commercial processing. Fish belonging to the family Clupeidae have high fatty acid content. High fatty acid content of fish is a potential to become a source of polyunsaturated fatty acids omega- 3 especially EPA and DHA. DHA and EPA provide benefits for human health were related to the prevention of cardiovascular disease, immunity, inflammation, allergies, and cancer ${ }^{3}$. This study aimed to determine proximate and fatty acids composition of spotted sardinella and goldstrip sardinella.

\section{MATERIALS AND METHOD}

Main materials used in this study were spotted sardinella (Amblygaster sirm) and goldstrip sardinella (Sardinella gibbosa). These materials were obtained from Muara Angke, North Jakarta, Indonsia. Other materials were materials used to proximate analysis and fatty acids analysis. The equipments used in this study were included equipments for preparation, such as knives, cutting boards, containers, trash bags, and digital scales. Another equipment was used for proximate analysis and analysis of fatty acid profiles.

Samples of fish was analyzed by a proximate analysis including water content (AOAC 2005, No. 934.01), ash (AOAC 2005, No. 938.08), protein (AOAC 2005, No. 976.05), and fat (AOAC 2005, No. 954.02), and analysis of fatty acid composition using instruments GC (Gas Cromatography) by AOAC (2005, No. 996.01)4.

\section{RESULTS AND DISCUSSION}

\section{Chemical Composition}

Chemical composition of fish was determined by proximate analysis. Proximate analysis was the analysis that be conducted to determine chemical composition of materials included water, protein, fat, ash, and carbohydrate. In general, the chemical composition of fish meat is composed of $66-84 \%$ water, protein of $15-24 \%$, fat 0.1 to $22 \%$, carbohydrates $1-3 \%$ and $0.8-2 \%$ inorganic material ${ }^{20}$. The amount of the chemical composition of fish meat varies depending on the species, sex, age, season and the environmental conditions in which the fish are caught. Chemical composition of Amblygaster sirm and Sardinella gibbosa can be seen in Table 1.

Table 1 showed that the highest water content of spotted sardinella shown at meat which amounted to $77.32 \%$. The highest ash content was found in head equal to $8.15 \%$. Viscera of spotted sardinella had the highest fat content of $7.30 \%$, but had the lowest protein content. The highest protein content in spotted sardinella was found in whole part and meat, respectively, $19.57 \%$ and $17.99 \%$.

The highest water content in goldstrip sardinella was found in whole part amounted of $73.10 \%$, while in head was $70 \%$. Head of goldstrip sardinella had a higher ash content than whole was equal to $8.87 \%$, similarly with the fat content of $4.43 \%$. Whole part of goldstrip sardinella had protein content of $22.32 \%$, was higher than in head that is $20.75 \%$.

Study of Karakoltsidis et al. ${ }^{12}$ showed levels of proximate fish of the family Clupeidae (pilchards) were arrested in three seasons, namely spring, autumn, and winter contain high levels of protein in the range of $16 \pm 1.7 \%$ to $18 \pm 1.2 \%$, fat content of $2 \pm 0.4 \%$ to $6 \pm 0.9 \%$, the water content was $74 \pm 0.5 \%$ to $76 \pm 0.1 \%$, and ash content of $1 \pm 0.1 \%$ to $2 \pm 0.1 \%$. In study Palani kumar et al. ${ }^{15}$ reported that the fishes of the families Carangidae, Clupeidae, Lutjanidae and Nemipteridae had the average moisture contents between 71 and $75 \%$. Majority of the fish family Clupeidae had the average protein contents between 15 to $20 \%$. The fish species of the family Clupeidae had medium fat contents between 3.2 and $6.8 \%$. The 
Table 1: Chemical composition of Amblygaster sirm and Sardinella gibbosa

\begin{tabular}{|c|c|c|c|c|}
\hline Part of fish & Water (\%) & Ash (\%) & Fat (\%) & Protein (\%) \\
\hline \multicolumn{5}{|c|}{ Amblygaster sirm (spotted sardinella) } \\
\hline Head & 70.52 & 8.15 & 2.10 & 14.07 \\
\hline Viscera & 70.11 & 1.58 & 7.30 & 13.46 \\
\hline Meat & 77.32 & 0.90 & 0.90 & 17.99 \\
\hline Skin & 76.47 & 1.58 & 0.53 & 17.42 \\
\hline Whole & 68.57 & 5.45 & 3.51 & 19.57 \\
\hline \multicolumn{5}{|c|}{ Sardinella gibbosa (goldstrip sardinella) } \\
\hline Head & 70 & 8.87 & 4.43 & 20.75 \\
\hline Whole & 73.10 & 7.87 & 4.3 & 22.32 \\
\hline
\end{tabular}

Table 2: Fatty acid profile of Amblygaster sirm (spotted sardinella)

\begin{tabular}{|c|c|c|c|c|c|}
\hline \multirow[t]{2}{*}{ Fatty acids } & \multicolumn{5}{|c|}{ A.sirm } \\
\hline & Head & Viscera & Meat & Skin & Unit \\
\hline C12:0 (Lauric acid) & 0.14 & 0.16 & 0.16 & 0.14 & $\% w / w$ \\
\hline C13:0 (Tridecanoic acid) & 0.08 & 0.10 & 0.06 & 0.07 & $\% \mathrm{w} / \mathrm{w}$ \\
\hline C14:0 (Myristic acid) & 1.34 & 4.28 & 3.29 & 3.89 & $\% w / w$ \\
\hline C15:0 (Pentadecanoic acid) & 0.95 & 1.13 & 0.81 & 0.90 & $\% w / w$ \\
\hline C16:0 (Palmitic acid) & 17.40 & 19.98 & 16.31 & 18.25 & $\% w / w$ \\
\hline C17:0 (Heptadecanoic acid) & 1.3 & 1.65 & 1.29 & 1.37 & $\% w / w$ \\
\hline C18:0 (Stearic acid) & 7.24 & 9.05 & 7.00 & 7.71 & $\% w / w$ \\
\hline C20:0 (Arachidic acid) & 0.53 & 0.66 & 0.56 & 0.59 & $\% w / w$ \\
\hline C21:0 (Heneicosanoic acid) & 0.13 & 0.18 & 0.13 & 0.15 & $\% w / w$ \\
\hline C22:0 (Behenic acid) & 0.38 & 0.42 & 0.43 & 0.42 & $\% w / w$ \\
\hline C24:0 (Lignoseric acid) & 0.56 & 0.36 & 0.36 & 0.35 & $\% w / w$ \\
\hline Total SFA & 30.05 & 37.97 & 30.40 & 33.84 & $\% w / w$ \\
\hline C14:1 (Myristoleic acid) & - & 0.02 & - & - & $\% w / w$ \\
\hline C16:1 (Palmitoleic acid) & 3.65 & 3.33 & 2.44 & 3.04 & $\% w / w$ \\
\hline C17:1 (cis-10-Heptadecanoic acid) & 0.21 & 0.24 & 0.14 & 0.18 & $\% \mathrm{w} / \mathrm{w}$ \\
\hline C18:1n9t (Elaidic acid) & 0.09 & 0.10 & 0.07 & 0.09 & $\% w / w$ \\
\hline C18:1n9c (Oleic acid) & 5.75 & 5.87 & 4.18 & 4.72 & $\% \mathrm{w} / \mathrm{w}$ \\
\hline C20:1 (cis-11-eicosanoic acid) & 0.36 & 0.55 & 0.19 & 0.36 & $\% w / w$ \\
\hline C22:1n9 (Erucic acid) & 0.06 & 0.09 & 0.07 & 0.07 & $\% w / w$ \\
\hline C24:1 (Nervonic acid) & 0.51 & 0.46 & 0.41 & 0.47 & $\% w / w$ \\
\hline Total MUFA & 10.63 & 10.66 & 7.50 & 8.93 & $\% w / w$ \\
\hline C18:2n6c (Linoleic acid) & 0.86 & 1.24 & 0.89 & 0.89 & $\% w / w$ \\
\hline C18:3n6 (ã-Linolenic acid) & 0.08 & 0.13 & 0.08 & 0.09 & $\% w / w$ \\
\hline C18:3n3 (Linolenic acid) & 0.17 & 0.15 & 0.45 & 0.18 & $\% w / w$ \\
\hline C20:2 (cis-11, 14-eicosadienoic acid) & 0.15 & 0.18 & 0.18 & 0.16 & $\% w / w$ \\
\hline C20:3n6 (cis-8, 11, 14-eicosetrienoic acid) & 0.09 & 0.11 & 0.1 & 0.11 & $\% \mathrm{w} / \mathrm{w}$ \\
\hline C20:4n6 (Arachidonic acid) & 1.10 & 2.19 & 1.47 & 1.64 & $\% w / w$ \\
\hline $\mathrm{C} 20 ; 5 \mathrm{n} 3$ (EPA) & 3.47 & 5.63 & 4.04 & 4.05 & $\% \mathrm{w} / \mathrm{w}$ \\
\hline C22:6n3 (DHA) & 11.00 & 21.32 & 18.99 & 17.37 & $\% w / w$ \\
\hline Total PUFA & 16.92 & 30.95 & 26.20 & 24.49 & $\% \mathrm{w} / \mathrm{w}$ \\
\hline Total fatty acids & 57.60 & 79.58 & 64.10 & 67.26 & $\% w / w$ \\
\hline Total fatty acids not detected & 42.40 & 20.42 & 35.90 & 32.74 & $\% w / w$ \\
\hline
\end{tabular}


fishes of the family Clupeidae contained $<2 \%$ ash contents. Saldanha et al. ${ }^{17}$ stated that the chemical composition of the species of sardine (Sardinella $\mathrm{sp}$.) is closely related to nutrition, habitat, size of fish, fishing seasons, months of arrest, and gender as variations in environmental conditions. In this study, viscera of spotted sardinella had the highest fat content. This is because the fat in mortal body is kept of $45 \%$ at around organs and abdominal cavity ${ }^{2}$. Fish can be grouped into four categories according to their fat contents: lean fish (<2\%), low fat $(2-4 \%)$, medium fat $(4-8 \%)$ and high fat $(>8 \%)^{1}$.

\section{Fatty Acid Profile}

Fish is the best source of fatty acids especially PUFA. Fatty acid profile includes SFA (Saturated Fatty Acids), MUFA (Mono Unsaturated Fatty Acids) and PUFA (Poly Unsaturated Fatty Acids). Fatty acid profile of small pelagic fish was analyzed by using gas chromatography. Fatty acid profile of spotted sardinella and goldstrip sardinella were presented in Table 2 and 3.

Table 2 showed that the highest fatty acid content in the SFA for all part of $A$. sirm was palmitic acid, which is the highest palmitic acid contained in

Table 3: Fatty acid profile of Sardinella gibbosa (goldstrip sardinella)

\begin{tabular}{lcc}
\hline Fatty acids & Whole part of S.gibbosa & Unit \\
\hline C12:0 (Lauric acid) & 0.08 & $\% \mathrm{w} / \mathrm{w}$ \\
C13:0(Tridecanoic acid) & 0.06 & $\% \mathrm{w} / \mathrm{w}$ \\
C14:0 (Myristic acid) & 7.16 & $\% \mathrm{w} / \mathrm{w}$ \\
C15:0 (Pentadecanoic acid) & 0.66 & $\% \mathrm{w} / \mathrm{w}$ \\
C16:0 (Palmitic acid) & 15.93 & $\% \mathrm{w} / \mathrm{w}$ \\
C17:0 (Heptadecanoic acid) & 0.78 & $\% \mathrm{w} / \mathrm{w}$ \\
C18:0 (Stearic acid) & 4.39 & $\% \mathrm{w} / \mathrm{w}$ \\
C20:0 (Arachidic acid) & 0.49 & $\% \mathrm{w} / \mathrm{w}$ \\
C21:0 (Heneicosanoic acid) & 0.10 & $\% \mathrm{w} / \mathrm{w}$ \\
C22:0 (Behenic acid) & 0.28 & $\% \mathrm{w} / \mathrm{w}$ \\
C24:0 (Lignoseric acid) & 0.34 & $\% \mathrm{w} / \mathrm{w}$ \\
Total SFA & 30.27 & $\% \mathrm{w} / \mathrm{w}$ \\
C14:1(Myristoleic acid) & 0.02 & $\% \mathrm{w} / \mathrm{w}$ \\
C16:1(Palmitoleic acid) & 5.35 & $\% \mathrm{w} / \mathrm{w}$ \\
C17:1(Cis-10-Heptadecanoic acid) & 0.44 & $\% \mathrm{w} / \mathrm{w}$ \\
C18:1n9t (Elaidic acid) & 0.10 & $\% \mathrm{w} / \mathrm{w}$ \\
C18:1n9c (Oleic acid) & 4.98 & $\% \mathrm{w} / \mathrm{w}$ \\
C20:1(Cis-11-Eicosanoic acid) & 0.95 & $\% \mathrm{w} / \mathrm{w}$ \\
C24:1 (Nervonic acid) & 0.54 & $\% \mathrm{w} / \mathrm{w}$ \\
Total MUFA & 12.38 & $\% \mathrm{w} / \mathrm{w}$ \\
C18:2n9t (Linolelaidic acid) & 0.04 & $\% \mathrm{w} / \mathrm{w}$ \\
C18:2n6c (Linoleic acid) & 0.99 & $\% \mathrm{w} / \mathrm{w}$ \\
C18:3n6 (ã-linoleic acid) & 0.16 & $\% \mathrm{w} / \mathrm{w}$ \\
C18:3n3(Linolenic acid) & 0.39 & $\% \mathrm{w} / \mathrm{w}$ \\
C20:2(Cis11,14-Eicosadienoic acid) & 0.16 & $\% \mathrm{w} / \mathrm{w}$ \\
C20:3n6 (Cis-11,14-Eikosatrienoat) & 0.19 \\
C20:4n6 (Arachidonic acid) & 2.12 & \\
C20:5n3 (EPA) & 6.8 & \\
C22:6n3 (DHA) & 12.18 & \\
Total PUFA & 23.03 & 65.68 \\
Total fatty acids & 34.32 & \\
Total fatty acids not detected & & \\
& & \\
\hline
\end{tabular}


viscera of $19.98 \%$, while for head, meat and skin respectively $17.40,16.31$, and $18.25 \%$. In the MUFA, the highest fatty acid content for all part was oleic acid, which is the highest oleic acid contained in viscera of $5.97 \%$, followed by head of $5.75 \%$, skin of $4.72 \%$, and meat of $4.18 \%$. The highest content of fatty acid in PUFA was DHA, which is the highest DHA contained in viscera of $21.32 \%$, while in head of $11.00 \%$, meat of $18.99 \%$, and skin of $17.37 \%$. Viscera was part of A.sirm that containing the highest of fatty acids SFA, MUFA and PUFA. Study of Ranasinghe and Attygalle ${ }^{16}$ reported that fatty acid composition in the three length classes in whole of Amblygaster sirm. The study showed that the highest content of SFA was palmitic acid, which is in length class $<15 \mathrm{~cm}$ was $29.04 \%, 15-20 \mathrm{~cm}$ was $27.32 \%$, and $>20 \mathrm{~cm}$ was $15.37 \%$. Oleic acid (MUFA) in length class $<15 \mathrm{~cm}$ was $7.45 \%, 15-20 \mathrm{~cm}$ was $11.6 \%$, and $>20 \mathrm{~cm}$ was $15.09 \%$. The highest content of PUFA was DHA, which is in length class $<15 \mathrm{~cm}$ was $24.49 \%, 15-20 \mathrm{~cm}$ was $15 \%$, and $>20 \mathrm{~cm}$ was $6.21 \%$. The most abundant fatty acid in was palmitic acid (16:0). Like in most other fish the polyunsaturated fatty acids were dominated by two members of the n-3 family, that is C20:5n-3 (eicosapentaenoic acid or EPA) and C22:6n-3 (docosahexaenoic acid or $\mathrm{DHA})^{16}$. Crexi et al. ${ }^{5}$ stated that the palmitic acid is a saturated fatty acid composition of the dominant with $50 \%$ of the total saturated fatty acids. Oleic acid is one of unsaturated fatty acids that is the most common and are precursors for production of PUFAs ${ }^{2}$.

Shirai et al. ${ }^{18}$ stated that the fatty acid content of different sardine species was significantly influenced by the amount consumed plankton and fish habitat conditions. The presence of omega-3 in fish is not only derived from the synthesis process of the fish's body, but also from fish food in the form of micro-organism, that is chlorella, diatoms, and dinoflagellates. The third of micro algae as long as is synthesizing omega 3 , also synthesize omega 6 . Moreover, it can also be synthesized by bacteria mold and other phytoplankton with level of omega 3 is different ${ }^{11}$.

Table 3 showed that the highest fatty acid contents were palmitic acid (C16:0) of $15.93 \%$ in saturated fatty acids (SFA), palmitoleic acid (C16:1) was $5.35 \%$ in monounsaturated fatty acids (MUFA) and $\mathrm{DHA}(\mathrm{C} 22: 6 \mathrm{n} 3)$ was $12.18 \%$ in poly unsaturated fatty acids (PUFA). Total saturated fatty acids in this fish were higher than unsaturated fatty acids. In study Nisa and Asadullah ${ }^{14}$ reported that in January, the highest total fatty acids in S.gibbosa were C16: 0 of $24.0 \%$ in the SFA, C18: 1 of $9.5 \%$ in the MUFA, C22: 6 of $19.1 \%$ in the PUFA, with a total of lipid was $7.5 \%$. Environmental factor such as season, temperature and diet as well as biological differences like age, sex, and size are known to affect the lipid composition $^{19}$.

\section{CONCLUSION}

This study concluded that the highest water content of spotted sardinella was fond in meat $(77.32 \%)$. The highest ash content was found in head $(8.15 \%)$. The highest fat content was found in viscera $(7.30 \%)$. The highest protein content in spotted sardinella was in whole part and meat, respectively, $19.57 \%$ and $17.99 \%$. The highest water content in goldstrip sardinella was found in whole part $(73.10 \%)$. Head of goldstrip sardinella had a higher ash content than whole was equal to $8.87 \%$, similarly with the fat content of $4.43 \%$. Whole part of goldstrip sardinella had protein content of $22.32 \%$. Viscera was part of spotted sardinella (A.sirm) that containing the highest of fatty acids, that is palmitic acid of SFA (19.98\%), oleic acid of MUFA (5.97\%) and DHA of PUFA (21.32\%). The highest fatty acid contents for goldstrip sardinella (S.gibbosa) were palmitic acid (C16:0) of $15.93 \%$ in saturated fatty acids (SFA), palmitoleic acid (C16:1) was 5.35\% in monounsaturated fatty acids (MUFA) and DHA (C22: $6 n 3$ ) was $12.18 \%$ in poly unsaturated fatty acids (PUFA).

\section{REFERENCES}

1. Ackman, R.G. Prog Food Nutr Sci. 1989, 13, 161-289.

2. Alamatsier Y., Basic Principles of Nutrition
Sciences (In Indonesia: Prinsip Dasar IImu Gizi), Vol VI.; Gramedia. Jakarta, (2006).

3. Alasalvar C. and Taylor T., Seafoods - Quality, 
Technology and Nutraceutical Applications. Springer. New York, (2002).

4. AOAC, Association of Official Analytical and Chemistry., Official Method of Analysis of The Association of Official Analytical of Chemist. Association of Official Analytical and Chemists, Inc. Arlington, Virginia, (2005).

5. Crexi, V.T.; Maurucio, L.M.; Leonor, Ad.Z.S.; Luiz, A.A.P. Food Chem. 2010, 119, 945-950.

6. Dalzell P.J., Small Pelagic Fishes. In: Nearshore Marine Resources of The South Pasific. Wright A, Hill L, editor. Institute Pasific Studies. Suva, (1993).

7. Indonesian Ministry of Marine Affairs and Fisheries., Marine And Fisheries In Figures 2013. Centre of Data, Statistics and Information. www.statistik.kkp.go.id. Jakarta, (2013a).

8. Indonesian Ministry of Marine Affairs and Fisheries., Marine and Fisheries Statistics Book 2012. Centre of Data, Statistics and Information. www.statistik.kkp.go.id. Jakarta, (2013b).

9. Indonesian Ministry of Marine Affairs and Fisheries., Spotted sardinella. www.sdi.kkp. go.id. (2014a).

10. Indonesian Ministry of Marine Affairs and
Fisheries., Goldstrip sardinella. www.sdi.kkp. go.id. (2014b).

11. Kaban, J.; Daniel. Jurnal Komunikasi Penelitian. 2005, 17, 16-23.

12. Karakoltsidis, P.A.; Zotos, A.; Constantinides. J. Food Composition and Analysis. 1995, 8, 258-273.

13. Love R.M., The Chemical Biology of Fishes. Brown ME (Edn). Academic press. New York, (1980).

14. Nisa, K.; Asadullah. J.Chem.Soc.Pak. 2008, 36, 436-441.

15. Palani kumar, M.; Ruba, A. A.; Jeya, S. R.; Shanmugam, S.A. J. Nutr. Food. Sci. 2014, 4, 1-7. doi: 10.4172/2155-9600.1000259

16. Ranasinghe, T.R.; Attygalle, M.V.E. Vidyodaya J.of Sci. 2009, 14, 59-66.

17. Saldanha, T.; Benassi, M.T.; Bragagnolo, N. LWT. 2008, 41, 1301-1309.

18. Shirai, N.; Suzuki, H.; Tokairin, S.; Ehara, H.; Wada, S. J Comparative Biochemistry and Physiology. 2002, 132, 609-619.

19. Stansby, M.E. J. Am. Oil Chem. Soc. 1981, 58, 13-16.

20. Suzuki T., Fish and Krill Protein in Processing Technology. Applied Science Publishing. Ltd. London, (1981). 